\title{
Knowledge and attitude towards dental trauma management among primary school teachers
}

\author{
Fadzlinda Baharin ${ }^{1 *}$, Nor Fatimah Osman², Munirah Mohd Adnan ${ }^{3}$ \\ 1Department of Paediatric Dentistry, School of Dental Sciences Universiti Sains Malaysia, Malaysia \\ ${ }^{2}$ Balok Dental Clinic, Ministry of Health, Kuantan, Malaysia \\ ${ }^{3}$ Department of Dental Public Health, School of Dental Sciences Universiti Sains Malaysia, Malaysia
}

\section{ABSTRACT}

Introduction: Dental injuries could happen anywhere, including in the school compound. Correct management by the teachers in dental emergencies could prevent further damage to the traumatized tooth and improve the success rate of the treatment. Hence, the purpose of this study was to assess the knowledge and attitude towards dental trauma management among the primary school teachers in Kubang Kerian area. Methods: This descriptive study was conducted in three national primary schools in Kubang Kerian and multi-stages sampling was performed to select the subjects. One hundred and twenty teachers $(n=120)$ were randomly selected and responded to a set of a self-administered questionnaire. The questionnaire consisted of general characteristics, knowledge, and attitude towards dental trauma. Results: A total of 120 primary school teachers, predominantly female teachers (74.2\%) participated in this study. More than half of the teachers (62.5\%) have more than 15 years of teaching experience. Onethird of the teachers (34.2\%) have completed first aid training; however, dental trauma management subject was lacking $(1.7 \%)$. About $31.7 \%$ of the respondent had experienced dental trauma case. Eightyfive percent of the teachers did not opt for tooth replantation in the case of avulsion and almost all the teachers $(97.5 \%)$ did not choose fresh milk as the medium storage of the avulsed tooth. Conclusion: The level of knowledge and attitude on dental trauma management among school teachers is unsatisfactory. As a recommendation, first aid training given to the teachers should include basic knowledge of dental trauma management. The awareness can be improved by organizing talk or campaign on dental trauma management at the school level.

Keywords: Children, dental trauma, school teachers.

p-ISSN 1979-0201, e-ISSN 2549-6212; Available from: http://jurnal.unpad.ac.id/pjd/article/view/24740

DOI: 10.24198/pid.vol31no1.24740

Submission: Oct 22, 2019; Accepted: Nov 27, 2019; Published online: Nov 30, 2019

"Corresponding author: Fadzlinda Baharin, Department of Paediatric Dentistry, School of Dental Sciences, Universiti Sains Malaysia, Malaysia. Kubang Kerian, Kota Bharu, Kelantan, Malaysia, 55281. Phone: +60126992463; Email: lindabaharin@ usm.my 


\section{INTRODUCTION}

The prevalence of dental trauma is reported to be $6-59 \%$ and approximately one-third of children and toddlers sustained a traumatic dental injury. ${ }^{1}$ In preschool children, fall injuries are the most frequent cause of oral injuries. Meanwhile in school-age children, dental trauma are most often caused by fall injuries and collisions while playing and running, in which these occur mainly in the school complex or sports area during day time. ${ }^{2}$

Dental injuries can affect psychological and social well-being, leading to negative effects on a child's well-being that lessens their quality of life. ${ }^{3}$ Eating discomfort, unattractive smile, and difficulty in cleaning the teeth are among the impacts of untreated dental injuries. Negative social judgments are also directed to children with visible traumatic teeth by their peers, leading to low self-confidence and barrier to their social development. ${ }^{4}$

Immediate management of dental injuries has shown a favourable outcomes. In avulsion, for instance, immediate replantation or placing the avulsed tooth in a correct storage medium could reduce the risk of negative complications such as external inflammatory root resorption and ankyloses. ${ }^{5}$ Certainly, due to the high prevalence of dental trauma among children and the negative impacts following dental injuries, these warrant reasonable attention from the school teachers because children spend many hours at their school. Thus, school teachers should equip themselves with enough knowledge on dental trauma management in order to assist and offer immediate help to their students should they sustain dental injuries at school.

Several studies have shown unsatisfactory level of awareness among school teachers in relation to management of dental trauma. These worrying findings were also found in the developed countries such as United States ${ }^{6}$ and United Kingdom ${ }^{7}$. However, there is a scarce data on how teachers in Malaysia would respond to dental emergencies at school. Therefore, this study was aimed to evaluate the level of knowledge and attitude of the primary school teachers in Kubang Kerian area on dental trauma management.

\section{METHODS}

This cross-sectional study was conducted in Kubang Kerian, an area in Kelantan state which located at the northeast of Malaysia. A complete list of all primary schools in Kubang Kerian was obtained from the Kota Bharu District Education Office and simple random sampling was performed to select 3 out of total schools in Kubang Kerian area. The list of teachers worked in these schools was obtained after, and simple random sampling was conducted again to include only 40 teachers from each school. Teachers who speak Bahasa Malaysia were included; trainee teachers, however, were excluded from this study. The questionnaires were distributed manually to the selected participants.

Ethical clearance has been obtained from the Research Ethics Commitee of University Sains Malaysia with registry number of USM/ JEPeM/16030115. All of the respondents signed informed consent before participating. Prior to the distribution of the questionnaires, the author had obtained written permission to conduct the study from the Ministry of Education and Universiti Sains Malaysia.

The questionnaire used in this study was adapted from previous study by Caglar. ${ }^{8}$ It was translated into Bahasa Malaysia and face validation was carried out prior to data collection in which the reviewers had agreed that the items in the questionnaire were clear, no ambiguity, easy to understand and comprehensive. The questionnaire was divided into 3 parts: The Part 1 questionnaire was comprised of questions regarding demographic data; Part 2 contained questions regarding knowledge of available dental emergency services and management of dental avulsion, and Part 3 contained cases scenario relevant to the attitude about dental trauma. The responses to the questionnaires from all the participants were entered on to a database and descriptive data were analyzed using SPPS version 22.0 software.

\section{RESULTS}

The response rate in this study was $100 \%$. A total of 120 filled questionnaires were evaluated. 


\section{Part 1: Demographics section}

From all 120 respondents included in this study, as much as 89 subjects $(74.2 \%)$ were female and 31 subjects $(25.8 \%)$ were male. A total of $75(62.5 \%)$ of the participants had teaching experience for more than 15 years. From this study population, as much as $79(65.8 \%)$ of the teachers never had first aid training. Only $2(13.7 \%)$ of the teachers had received training on dental emergencies and as much as $38(31.6 \%)$ of the study participants had experienced dental trauma cases throughout their working experience.

Part 2: Knowledge of the available dental emergency services and management of dental avulsion

Emergency service knowledge and management of dental avulsion measuring by tooth replantation following transportation of an avulsed tooth.

Most of the participants (82.5\%) experienced dental trauma and almost half of the respondents $(49.2 \%)$ chose general dentists as the most suitable person to treat dental trauma among other emergency services. Most of the teachers (85\%) did not opt for tooth replantation in the case of avulsion as shown in Figure 1.

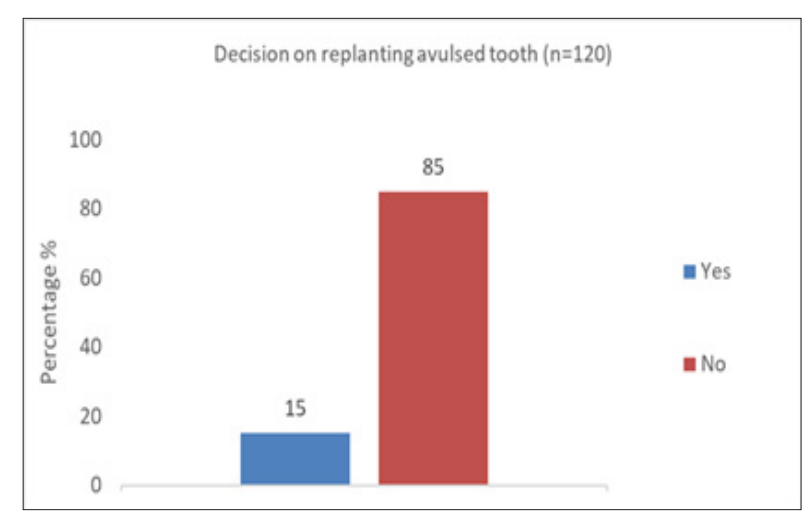

Figure 1. Knowledge of tooth replantation following avulsion

Meanwhile, Figure 2 shows the choice by the participants on different transportation vehicles if they refused to replant an avulsed tooth and wanted to bring the tooth to the dentist. Nearly half of the respondents $(45.8 \%)$ opted for tap water as the storage medium for an avulsed tooth as demonstrated in Figure 3.

\section{Part 3: Attitude towards dental trauma.}

The responses in this section were generally negative. For the first case scenario

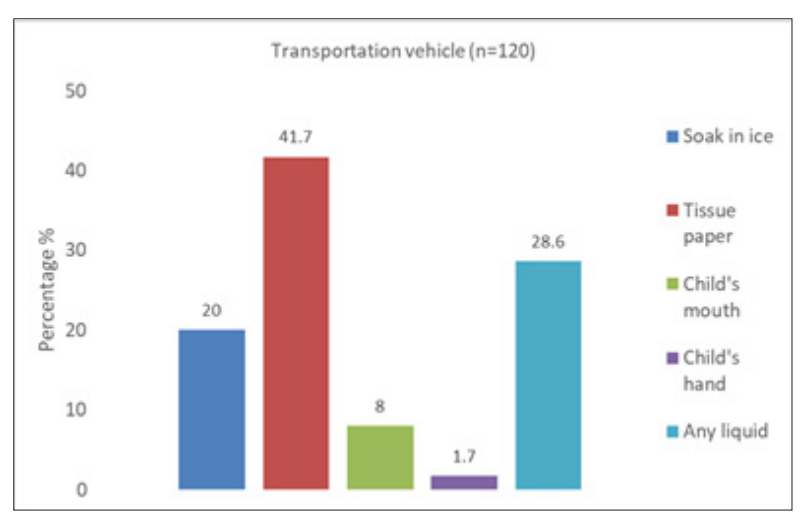

Figure 2. Knowledge of transportation vehicle of an avulsed tooth

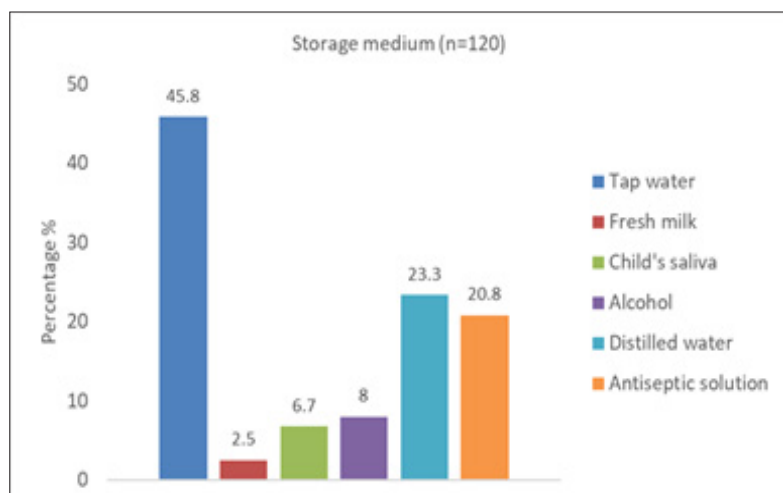

Figure 3. The knowledge of storage medium for an avulsed tooth

\begin{tabular}{lcc}
\multicolumn{1}{c}{ Attitude } & $\begin{array}{c}\text { Frequency } \\
(\mathrm{n}=120)\end{array}$ & $\begin{array}{c}\text { Percentage } \\
(100 \%)\end{array}$ \\
\hline $\begin{array}{l}\text { Case A: Fractured front tooth in a 9-year old student } \\
\text { Call parents after school hours }\end{array}$ & 7 & 5.8 \\
$\begin{array}{l}\text { Give warm drink to the } \\
\text { student and contact parents }\end{array}$ & 27 & 22.5 \\
$\begin{array}{l}\text { Send immediately to the } \\
\text { dentist }\end{array}$ & 44 & 36.7 \\
$\begin{array}{l}\text { Search for broken pieces of } \\
\text { the tooth }\end{array}$ & 6 & 5.0 \\
$\begin{array}{l}\text { Call parents and ask them to } \\
\text { bring to dentist } \\
\text { Did not express any attitude }\end{array}$ & 28 & 23.3 \\
\hline
\end{tabular}

about a fractured front tooth in a 9-year-old student, more than half $(63 \%)$ of the participants answered incorrectly for the question on type of dentition. Only five percent (5\%) of the respondents would search for the broken fragment of the fractured tooth while 44 respondents would send the child to see dentist straightaway (Table 1). In the second case scenario on avulsion of front tooth in a 12-year-old student, more than two-thirds of the teachers $(69.2 \%)$ choose to attend the bleeding gum as immediate management meanwhile less 
than one-quarter of the respondents (19.2\%) would search for the avulsed tooth for replantation as described in Table 2.

Table 2. Attitude towards tooth avulsion

\begin{tabular}{|c|c|c|}
\hline Attitude & $\begin{array}{l}\text { Frequency } \\
(n=120)\end{array}$ & $\begin{array}{l}\text { Percentage } \\
\quad(100 \%)\end{array}$ \\
\hline \multicolumn{3}{|c|}{ Case B: Avulsed front tooth in a 12-year old student } \\
\hline $\begin{array}{l}\text { Ask student to bite on } \\
\text { handkerchief (bleeding) }\end{array}$ & 83 & 69.2 \\
\hline $\begin{array}{l}\text { Find the tooth, wash, for } \\
\text { student to bring it home }\end{array}$ & 11 & 9.1 \\
\hline $\begin{array}{l}\text { Find the tooth and put in the } \\
\text { socket }\end{array}$ & 6 & 5.0 \\
\hline $\begin{array}{l}\text { Put the tooth in any liquid and } \\
\text { send student home }\end{array}$ & 3 & 2.5 \\
\hline $\begin{array}{l}\text { Put the tooth in the socket } \\
\text { and bring them to dental } \\
\text { clinic }\end{array}$ & 17 & 14.2 \\
\hline
\end{tabular}

\section{DISCUSSION}

The present study showed more than half of the school teachers did not receive any first-aid training before. As for the remaining teachers who had the training, only a small number of them were exposed to dental trauma management during the training. Lack of training on dental emergencies among school teachers is also found from other previously published studies. . $^{8-10}$ In Malaysia, the Ministry of Health runs a continuous dental education under school dental programs where the dental team conducts various oral health promotion activities such as dental checkups and talk at school.

Yet, little is known to which extent dental trauma topic is covered throughout the program. It is worth pointing out that $31.7 \%$ of the teachers in the present study had experienced dental trauma events among their students and this finding is quite worrying because only small proportion of them were trained on dental trauma management despite most of the teachers in this study were senior teachers. As a matter of fact, teachers should first have a sound knowledge regarding dental emergencies, in order to assist and take the necessary action in any kind of dental trauma. From this study, the overall knowledge and attitude of the teachers in the management of avulsion is poor. Most of the teachers (69.2\%) would rather focus on monitoring the bleeding gum and only a small proportion (19.2\%) of them would find and replant the missing tooth. This disturbing finding quite consistent with other studies by Hashim ${ }^{11}$ and Kaul ${ }^{12}$.

Presumably, teachers not aware that extraoral dry time is a determinant in improving the prognosis of an avulsed tooth and bleeding is perceived as a priority over the missing tooth. Having said this, majority of the teachers agreed that dental treatment should be provided immediately after the avulsion by means bring the student to the dentist. It indicates the teachers are aware of the importance of professional help following dental trauma. However, in avulsion, the necessary measures taken at on-site is far more significant with immediate replantation of the avulsed tooth is shown to have better outcomes. Disappointingly, most teachers did not willingly perform tooth replantation. In a study by MarcanCaldera ${ }^{13}$ involving 2296 school teachers, only $5.8 \%$ would have replanted an avulsed tooth. A low percentage was also observed in an American study conducted by Vergotine ${ }^{6}$, in which only $12 \%$ of the academic teachers and $7 \%$ of the physical education teachers would perform tooth replantation. The refusal to replant an avulsed tooth by the teachers could be due to lack of confidence and presumably to avoid doing more harm to the injured student. But, it could also purely due to inadequate knowledge on the drawbacks of not replanting.

Even though majority of teachers would seek help from dentist immediately following dental trauma, their on-site management prior to the visit, however, are found to be faulty. In the present study, quite a lot of teachers used the tap water to clean soiled avulsed tooth and as a storage medium. Storage in a tap water should be the last resort because of its hypotonicity, which would lead to necrosis of periodontal ligament cells. ${ }^{14}$ Fresh milk is easily available within school complex and should be a better option as storage medium for an avulsed tooth. It is worth highlighting that unfortunately, almost half of the teachers in the present study would keep the avulsed tooth in tissue paper prior visit to the dentist. This course of action is disastrous and will reduce the treatment success rate because extraoral dry time of more than 60 minutes would lead to the loss of normal physiologic metabolism and morphology of periodontal ligament cells. ${ }^{5}$ 
Approximately two-thirds of the teachers in this study were unaware of type of dentition in relation to the age of a child. In a scenariobased case given, most of them failed to recognize that a fractured front tooth would be permanent in a 9-year-old student. Contrary to Caglar's study, in which $85 \%$ of the respondents in their study correctly identified the type of dentition, despite their lack of training on dental trauma management. ${ }^{8}$ The vast difference in the percentage could possibly due to relatively good level of general knowledge in the European population. It is unfortunate in the present study that only $5 \%$ of teachers would search for pieces of the fractured tooth. The fragment reattachment is a conservative treatment in which it could directly restore the original dental anatomy and preserving dental tissues. ${ }^{15} \mathrm{~A}$ small number of teachers who are aware of reattachment treatment were also observed in the studies by Hassan', but a different finding was observed from a Hong Kong study in which majority of the teachers $(81 \%)$ would retrieve the fractured crown fragment for reattachment. ${ }^{16}$

Their unsatisfactory level of knowledge warrants intervention measures from the Ministry of Education. As a recommendation, first aid training should be made compulsory for teachers and the training must include modules consisting of basic dental trauma management. Continuous education such as talk or campaign should also be diligently carried out at the school level, targeting both teachers and school children.

\section{CONCLUSION}

Knowledge of the available dental emergency services and management of dental avulsion, most of the teachers did not opt for tooth replantation in the case of avulsion efused to replant an avulsed tooth and wanted to bring the tooth to the dentist. The responses of attitude towards dental trauma were generally negative.

\section{REFERENCES}

1. Lam R. Epidemiology and outcomes of traumatic dental injuries: A review of the literature. Aust Dent J. 2016; 61 Suppl 1: 4-20. DOI: $10.1111 /$ adj.12395.
2. Andersson L. Epidemiology of traumatic dental injuries. J Endod. 2013; 39(3): S2-S5. DOI: 10.1016/j.joen.2012.11.021

3. El-Kalla IH, Shalan HM, Bakr RA. Impact of Dental Trauma on Quality of Life Among 11-14 Years School Children. Contemp Clin Dent. 2017; 8(4): 538-44. DOI: $10.4103 / \mathrm{ccd}$. ccd $428 \quad 17$

4. Rodd HD, Barker C, Baker SR, Marshman Z, Robinson PG. Social judgements made by children in relation to visible incisor trauma. Dent Traumatol. 2010; 26(1): 2-8. DOI: 10.1111/j.1600-9657.2009.00849.x.

5. Andreasen JO, Andreasen FM, Skeie A, Hjørting-Hansen E, Schwartz O. Effect of treatment delay upon pulp and periodontal healing of traumatic dental injuries-a review article. Dent Traumatol. 2002;18(3):116-28. DOI: $10.1034 / j .1600-9657.2002 .00079 . x$

6. Vergotine RJ, Govoni R. Public school educator's knowledge of initial management of dental trauma. Dent Traumatol. 2010; 26: 133136. DOI: $10.1111 /$ j.1600-9657.2009.00854.x

7. O'Neill G. Dental trauma: Trauma protocol for schools. Br Dent J. 2018; 225(5): 376. DOI: 10.1038/sj.bdj.2018.765

8. Caglar E, Ferreira LP, Kargul B. Dental trauma management knowledge among a group of teachers in two south European cities. Dent Traumatol. 2005; 21(5): 258-262. DOI: 10.1111/j.1600-9657.2005.00321.x

9. Prasanna S, Giriraju A, Narayan NL. Knowledge and Attitude of Primary School Teachers toward Tooth Avulsion and Dental First Aid in Davangere City: A Cross-sectional Survey. Int J Clin Pediatr Dent. 2011; 4(3): 203-206. DOI:10.5005/jp-journals-10005-1110

10. Mehrabkhani M, Ajami B, Parisay I, Bolboli A, Akbarian G. Knowledge of Emergency Management of Traumatized Teeth among Schoolteachers in Mashhad, Iran. J Dent Res Dent Clin Dent Prospects. 2015; 9(2): 121-5. DOI: $10.15171 /$ joddd. 2015.024.

11. Hashim R. Dental trauma management awareness among primary school teachers in the Emirate of Ajman, United Arab Emirates. Eur J Paediatr Dent. 2011; 12(2): 99-102.

12. Kaul R, Jain P, Saha N, Goswami S, Mukhopadhyay $S$, Saha $S$, et al. Evaluation of knowledge, awareness, and attitude toward 
emergency dental trauma management among the school teachers of Kolkata. Indian J Dent Res. 2017; 28(6): 595-603. DOI: 10.4103/ijdr. IJDR_118_17

13. Marcano-Caldera M, Mejía-Cardona JL, Parra Sanchez JH, Méndez de la Espriella C, Covo Morales E, Sierra Varón G, et.al. Knowledge about emergency dental trauma management among school teachers in Colombia: A baseline study to develop an education strategy. Dent Traumatol. 2018; 34(3): 164-174. DOI: 10.1111/edt.12393

14. Blomlöf $\mathrm{L}$, Lindskog $\mathrm{S}$, Andersson $\mathrm{L}$, Hedström KG, Hammarström L. Storage of experimentally avulsed teeth in milk prior to replantation. J Dent Res. 1983; 62(8): 912-6. DOI: 10.1177/00220345830620081301

15. Ișeri U, Özkurt Z, Kazazoğlu E. Clinical management of a fractured anterior tooth with reattachment technique: a case report with an 8-year follow up. Dent Traumatol. 2011; 27(5): 399-403. DOI: 10.1111/j.16009657.2011.01015.X

16. Young C, Wong KY, Cheung LK. Emergency management of dental trauma: knowledge of Hong Kong primary and secondary school teachers. Hong Kong Med J. 2012 Oct;18(5):362-70. 